\title{
PENGGUNAAN OMNIBUS LAW DALAM REFORMASI REGULASI BIDANG LINGKUNGAN HIDUP DI INDONESIA ${ }^{1}$
}

\author{
Helmi*, Fitria, Retno Kusniati \\ Fakultas Hukum Universitas Jambi \\ Jl. Jambi-Muara Bulian KM. 11 Kampus Pinang Masak \\ helmi@unja.ac.id
}

\begin{abstract}
The sectoral and institutional clustering is the primary idea in this journal as an effort to conduct regulatory reform with omnibus-law in the living environment sector in Indonesia. This study uses a normative juridical analysis that addresses the following problems: Firstly, can sectoral and institutional clustering be relied on as the basis for regulatory reform in the living environment sector with the Omnibus-law? Secondly, can the law of Protection and Management of the Environment be relied on as the clusters to conduct regulatory reform in the living environment sector affairs in Indonesia? The conclusions are: Firstly, the sectoral and institutional clustering claimed as the basic principle to utilize Omnibus-law in Indonesia in term of regulatory reform in Indonesia includes the living environment sector. Secondly, the living environment affair is the sectoral clusters, thus Omnibus-law can be relied on as the methodology to establish the law of Environmental affairs the sectoral clusters which include part of sectoral clusters.
\end{abstract}

Keyword: Omnibus Law; Reformation of Regulation; Environmental.

\begin{abstract}
Abstrak
Perumpunan bidang dan kelembagaan merupakan ide utama tulisan ini dalam melakukan reformasi regulasi menggunakan omnibus law bidang lingkungan hidup di Indonesia. Studi ini menggunakan telaah yuridis normatif yang membahas permasalahan: Pertama, apakah aspek perumpunan bidang dan kelembagaan dapat dijadikan dasar reformasi regulasi bidang lingkungan hidup menggunakan omnibus law? Kedua, apakah bidang UU-PPLH dapat dijadikan sebagai rumpun untuk melakukan reformasi regulasi terhadap bidang-bidang sektoral lingkungan hidup di Indonesia? Kajian ini menghasilkan simpulan: Pertama, perumpunan bidang dan kelembagaan merupakan prinsip dasar penggunaan omnibus law di Indonesia untuk reformasi regulasi di Indonesia termasuk bidang lingkungan hidup. Kedua, lingkungan hidup merupakan rumpun bidang, maka omnibus law dapat dijadikan metode dalam pembentukan UU Lingkungan Hidup sebagai rumpun bidang yang mencakup sub-sub rumpun bidang di bawahnya.
\end{abstract}

Kata Kunci: Omnibus Law; Reformasi Regulasi; Lingkungan Hidup.

\footnotetext{
${ }^{1}$ Hasil Penelitian Terapan Bidang Hukum Lembaga Penelitian dan Pengabdian Kepada Masyarakat (LPPM) Universitas Jambi, dibiayai dana PNBP Fakultas Hukum Universitas Jambi Tahun 2020.
} 


\section{A. Pendahuluan}

Reformasi regulasi memang diperlukan untuk menyelesaikan hambatan investasi yakni panjangnya rantai birokrasi, peraturan yang tumpang tindih, dan banyaknya regulasi yang tidak harmonis baik tingkat nasional maupun lokal (daerah). Sayangnya dalam kurun waktu lebih tiga dasawarsa terakhir, politik pembangunan hukum nasional diarahkan pada anutan ideologi sentralisme hukum (legal centralism). Hal ini secara sadar dimaksudkan untuk mendukung paradigma pembangunan yang semata-mata diorientasikan untuk mengejar pertumbuhan ekonomi (economic growth development paradigm). Implikasinya, sumber daya alam sebagai modal utama pembangunan bukan dikelola secara berkelanjutan, tetapi justru dieksploitasi untuk mengejar target-target pertumbuhan ekonomi. Karena itu, instrumen hukum yang digunakan untuk mendukung paradigma pembangunan ekonomi seperti dimaksud di atas cenderung bercorak sentralistik, sektoral, memihak kepada pemodal besar (capital oriented), eksploitatif, dan bernuansa represif dengan menggunakan pendekatan sekuriti (security approach) (Nugroho, 2017).

Oleh karena itu, diperlukan deregulasi perizinan berusaha, persyaratan investasi, ketenagakerjaan, Usaha Mikro Kecil dan Menengah (UMKM), pengadaan lahan, pengembangan kawasan ekonomi, pelaksanaan proyek pemerintah, serta ketentuan mengenai administrasi pemerintahan dan pengenaan sanksi pidana yang diatur dalam berbagai undang-undang ("Naskah Akademik RUU Cipta Lapangan Kerja," 2020) yang terpisah satu sama lain. Permasalahan regulasi di Indonesia tidak hanya bisa diselesaikan melalui harmonisasi melainkan butuh terobosan hukum salah satunya menggunakan omnibus law. Konsep omnibus law yang diterapkan di beberapa negara seperti Amerika Serikat, Belgia, Inggris menawarkan pembenahan permasalahan timbulnya konflik dan tumpang tindih (overlapping) suatu norma/peraturan perundang-undangan. Bila hendak dibenahi satu persatu maka akan memakan waktu yang cukup lama dan biaya yang tidak sedikit (Busroh, 2017).

Omnibus Law merupakan sebuah praktik penyusunan peraturan perundangundangan, yang banyak dilakukan di negaranegara yang menganut sistem common law/anglo saxon seperti Amerika, Kanada, Inggris, Filipina dan lainnya. Prosesnya disebut Omnibus Legislating dan produknya disebut Omnibus Bill. Omnibus law, sebagai metode pembentukan peraturan bertujuan menyederhanakan regulasi di berbagai bidang. Jadi tidak hanya dilakukan terhadap bidang tertentu (Puspitawati, 2020), apalagi dibatasi pada pengaturan yang sangat teknis, tetapi kemudian pengaturan teknis tersebut justru mengubah bahkan membatalkan norma pokok.

Tujuan penggunaan omnibus law sangat ideal. Namun, praktik terhadap UU Cipta Kerja ternyata menuai banyak kritik dan permasalahan. Direktur LBH Jakarta, Arif Maulana memberi catatan sedikitnya 3 (tiga) hal terhadap omnibus law yang digulirkan pemerintah:

"Pertama, berpotensi menambah masalah dalam sistem hukum Indonesia. Kedua, perencanaan omnibus law ini terburu-buru dan tertutup. Ketiga, omnibus law RUU Cipta Lapangan Kerja berpotensi melanggar hak warga negara terutama buruh dan keluarganya yang dijamin konstitusi. Pasal 28D ayat (2) UUD Tahun 1945 yang menyebut setiap orang berhak untuk bekerja serta mendapat imbalan dan perlakuan yang adil dan layak dalam hubungan kerja" ("RUU Omnibus Law Dinilai Tak Punya Pijakan Hukum,” n.d.).

Asep Warlan Yusuf menegaskan RUU Omnibus Law Cipta Kerja bidang Lingkungan Hidup dan Kehutanan (LHK) pada prinsipnya tidak mengalami perubahan pada UU 32 Tahun 2009 tentang Perlindungan dan Pengelolaan Lingkungan Hidup (UUPLH). Berdasarkan data dari Kementerian Koordinator Perekonomian, pada Februari 2020 terjadi kompleksitas dan 
obesitas regulasi di pusat dan daerah, karena terdapat 43.511 peraturan. Penerapan metode omnibus law memiliki banyak kelebihan untuk menyelesaikan disharmoni regulasi di Indonesia. Kelebihan tersebut antara lain dapat mengatasi konflik peraturan perundang-undangan baik vertikal maupun horizontal secara cepat, efektif dan efisien. Selain itu mampu menyeragamkan kebijakan pemerintah baik di tingkat pusat maupun di daerah untuk menunjang iklim investasi. Omnibus law dapat memangkas pengurusan perizinan lebih terpadu, mampu memutus rantai birokrasi yang berbelit-belit, meningkatkan hubungan koordinasi antar instansi terkait karena telah diatur dalam kebijakan omnibus regulation yang terpadu, serta adanya jaminan kepastian hukum dan perlindungan hukum bagi para pengambil" ("Siaran Pers Telkom," n.d.).

Walaupun telah disahkan, tetap saja UU Cipta Kerja menyisakan ruang analisis mendalam bagi para ahli hukum. Permasalahan besar regulasi di Indonesia yakni saling bertentangan, ego sektoral dan ego kelembagaan, rendah koordinasi, tidak ada jaminan keadilan dan kepastian hukum, bahkan mungkin akan menghilangkan manfaatnya terhadap masyarakat utamanya buruh. UU Cipta Kerja menjadi "uji coba" penggunaan omnibus law di Indonesia yang mendahulukan kepentingan pertumbuhan investasi dengan cara memberi kemudahan dan kemurahan bagi calon investor. Walaupun tidak ada hukum dan peraturan yang dilanggar, termasuk UU No. 12 Tahun 2011 jo UU No. 15 Tahun 2019 tentang Pembentukan Peraturan PerundangUndangan.

"Zaenal

Arifin Mochtar

mempertanyakan sempitnya wacana omnibus law ini, yaitu terfokus pada masalah ekonomi. Padahal masih banyak lagi. Misalnya, peraturan terkait partai politik" (Sucahyo, n.d.). Pernyataan ini beralasan, kebutuhan reformasi regulasi Indonesia juga mendesak terhadap berbagai bidang yang saat ini masih berlaku dan potensi akan menghambat keberlakuan UU Cipta Kerja nantinya, termasuk regulasi bidang lingkungan hidup yang diatur dalam UU No. 32 Tahun 2009 (UU-PPLH).

Sesuai dengan makna konsep "lingkungan hidup", bahwa "lingkungan hidup mencakup bidang atau sektor yang selama digunakan istilah sumber daya alam, seperti kehutanan, pertambangan, perkebunan, pengairan dan kelautan. Bidang atau sektor ini sesungguhnya merupakan bagian dari lingkungan hidup, oleh karena itu lingkungan hidup yang diatur dalam UUPPLH merupakan rumpun bidang dan sektor merupakan sub-rumpun bidang. Maka, dalam praktik sub-sub rumpun bidang harus tunduk dan taat pada UU-PPLH" (Helmi, 2012) sebagai rumpunnya. Walaupun sejatinya substansi norma UU-PPLH menegaskan keterpaduan dalam perlindungan dan pengelolaan lingkungan di Indonesia yang mencakup keseluruhan bidang atau sektor, namun penyelenggaraan urusan masing-masing bidang atau sektor lingkungan hidup "berjalan" sendiri. Sistem perizinan tidak dapat dijangkau oleh UUPPLH yang "kalah kuat" dengan UU sektoral, terutama dalam rangka meningkatkan pertumbuhan ekonomi negara dan keuntungan bagi pemegang izin usaha atau kegiatan. Sistem perizinan terpadu yang diamanatkan malah dianggap merugikan kementerian sektoral. Institusi yang mengurus lingkungan hidup seringkali dijadikan sasaran kesalahan jika terjadi kerusakan dan atau pencemaran lingkungan hidup.

Persetujuan oleh DPR tanggal 5 Oktober 2020 membawa perubahan pada pengaturan rumpun bidang lingkungan hidup. UU-PPLH, beserta UU sektoral bidang lingkungan hidup termasuk normanya yang diubah, dihapus dan diganti yang baru oleh UU Cipta Kerja. Namun UUPPLH dan UU sub-sub rumpunnya masih tetap berlaku, sehingga berpotensi menimbulkan ketidakpastian dan ketidakmanfaatan dalam penyelenggaraan urusan bidang ini.

Oleh karena itu, reformasi regulasi melalui omnibus law terhadap rumpun bidang lingkungan hidup mendesak 
dilakukan, namun dengan pembatasan terhadap sub-sub rumpun bidang seperti kehutanan, pertambangan, pertambangan, pengairan dan kelautan dan lain-lain sesuai dengan lingkup rumpun ini. Pembatasan ini dimaksudkan agar penggunaan omnibus law di Indonesia memunculkan keadilan, kepastian dan kemanfaatan hukum.

Kajian ini merupakan kajian yang memiliki nilai orisinalitas dari penelitianpenelitian yang pernah dilakukan sebelumnya. Ruang lingkup kajian yang spesifik membahas mengenai penggunaan omnibus law dalam reformasi regulasi bidang lingkungan hidup di Indonesia merupakan kekhususan yang menunjukkan kebaruan tulisan ini.

Berdasarkan uraian latar belakang, ditentukan dua permasalahan hukum yang menjadi pokus dalam penelitian ini. Pertama, apakah aspek perumpunan bidang dan kelembagaan dapat dijadikan dasar reformasi regulasi bidang lingkungan hidup menggunakan omnibus law? Kedua, apakah bidang UU-PPLH dapat dijadikan sebagai rumpun untuk melakukan reformasi regulasi terhadap bidang-bidang sektoral lingkungan hidup di Indonesia?

\section{B. Metode Penelitian}

Tulisan ini hasil merupakan hasil kajian yuridis normatif yang "menelaah kaidahkaidah, norma-norma, aturan-aturan,yang berhubungan dengan masalah yang akan diteliti" (Nasution, 2008). Sesuai dengan rumusan masalah dan tujuan, penelitian ini menggunakan pendekatan perundangundangan, dan pendekatan konseptual. Kedua pendekatan ini digunakan untuk menganalisis dan menemukan "prinsip umum" dalam melakukan reformasi regulasi bidang lingkungan menggunakan omnibus law. UU bidang lingkungan dan konsepkonsep terkait keterpaduan yakni perumpunan bidang dan kelembagaan menjadi poin utama dalam hal ini.

\section{Hasil dan Pembahasan}

\section{Perumpunan Bidang dan Kelembagaan sebagai Dasar Reformasi Regulasi Bidang Lingkungan Hidup Menggunakan Omnibus Law}

Sistem hukum terdiri dari "elemenelemen yakni kelembagaan, kaidah aturan dan perilaku para subyek hukum". Ketiga elemen hukum tersebut mencakup: “(a) kegiatan pembuatan hukum (law making), (b) kegiatan pelaksanaan atau penerapan hukum (law administrating), (c) kegiatan peradilan atas pelanggaran hukum (law adjudicating) atau yang biasa disebut dengan penegakan hukum dalam arti sempit (law enforcement)"(Asshiddiqie, 2005).

Sebagai negara hukum, segala aspek kehidupan harus berdasarkan hukum sesuai dengan sistem hukum nasional merupakan hukum yang berlaku di Indonesia dengan semua elemennya dalam rangka mencegah atau mengatasi permasalahan hukum. "Salah satu elemen dalam sistem hukum nasional adalah sistem peraturan perundangundangan yang juga merupakan aspek yang sangat penting dalam penyelenggaraan pemerintahan" (Anggono, 2014).

Konstitusi sebagai norma dasar (the basic norm) sistem hukum nasional dan menjadi pengikat simpul tatanan peraturan dalam Negara hukum Indonesia. Seluruh agenda penyelenggaraan negara, termasuk pembentukan peraturan di bawah UUD wajib berdasarkan didasarkan pada konstitusi. Jika terdapat pertanyaan, dari mana memulai melakukan reformasi tatanan peraturan di Indonesia? Maka jawabannya UUD 1945 menjadi norma dasar sebagai simpul pengikat seluruh rumpun bidang dan kelembagaan dalam rangka penggunaan omnibus law dengan khas Indonesia.

Peraturan merupakan norma yang dihasilkan dari legislasi konstitusi. Menurut Salmond, "terdapat dua jenis legislasi, yaitu legislasi utama (supreme legislation) dan legislasi delegasian (subordinate legislation). Legislasi utama ditetapkan oleh lembaga pemegang kedaulatan dalam 
negara. Legislasi utama ini tidak dapat dicabut, dihilangkan atau dikontrol oleh lembaga legislatif lain. Di lain pihak, legislasi delegasian merupakan produk dari lembaga lain di luar lembaga pemegang kedaulatan. Keberadaan dan keabsahan dari legislasi delegasian ini tergantung kepada lembaga yang mempunyai wewenang lebih tinggi" (Widiati, 1945). Konstitusi merupakan produk legislasi utama, sementara peraturan di bawahnya merupakan produk legislasi delegasian. Konsekuensi sebagai legislasi utama, konstitusi menjadi landasan bagi hukum positif baik dalam bentuk tertulis dan tertulis. Pembuat peraturan (delegasi legislasi) yang diberi wewenang oleh konstitusi untuk membuat norma-norma hukum yang bersifat umum.

Pembentukan norma hukum positif, bagian dari politik hukum suatu negara. "Politik hukum senantiasa berupaya membuat hukum cita (ius constituendum) yang kelak menjadi hukum positif yang baru (ius constitutum) yang sesuai dengan tuntutan kebutuhan dan dinamika perkembangan masyarakat. Melalui politik hukum, pemerintah dapat melakukan pembaruan-pembaruan hukum di semua aspek dan menyesuaikan dengan tuntutan masyarakat, baik dalam skala nasional maupun internasional" (Irwansyah, 2020).

Agar politik hukum yang menghasilkan pembaruan yang berkeadilan, penggunaan "omnibus law" dalam reformasi regulasi di Indonesia, termasuk bidang lingkungan hidup perlu dilakukan terpadu dan menyeluruh untuk menemukan " prinsip umum" yang akan dijadikan "pijakan pokok" sebagai awal penggunaan "omnibus law" itu sendiri. Setelah prinsip umum tersebut ditemukan dan ditetapkan, langkah selanjutnya dalam omnibus law baru bisa dilakukan. Di antara prinsip umum sebagai pijakan pokok dimaksud yakni sistem perumpunan bidang dan kelembagaan.

Erat kaitannya dengan perumpunan, dalam ilmu hukum dikenal teori sistem, pada dasarnya adalah suatu studi antar-disiplin dari suatu sistem yang umum dengan tujuan utamanya menemukan pola-pola dan menjelaskan prinsip-prinsip yang bisa diaplikasikan terhadap bentuk sistem dalam semua cabang ilmu. Penemu teori ini adalah Karl Ludwig von Bertalanffy (1901-1972), seorang biologist dari Austria dan dikenal sebagai penemu GST "Teori Sistem Umum (General System Theory)". Aslinya teori ini dimaksudkan untuk menjelaskan sistem yang terkait dan saling berinteraksi dengan komponen-komponen lainnya dan diaplikasikan dalam ilmu biologi dan cybernetics, serta sistem lainnya (Wiratmadinata, 2018).

Teori di atas jika dikaitkan dengan sistem hukum, maka UUD 1945 merupakan sistem yang terdiri rumpun-rumpun sebagai pijakan awal dalam reformasi regulasi di Indonesia. UUD 1945 memuat pokok-pokok dan prinsip-prinsip umum dalam kehidupan berbangsa dan bernegara. Berdasarkan sistematika batang tubuh UUD 1945 rujukan utama yakni bab-bab yang penamaannya telah menunjukkan bidang-bidang dan kelembagaan penyelenggaran negara di Indonesia (Helmi, Syam, Nopyandri, \& Putra, 2020).

Berikut rumpun-rumpun bidang dan kelembagaan yang terdapat dalam UUD 1945 yakni: Kekuasaan Legislatif, Kekuasaan Pemerintahan Negara dalam lingkup fungsi eksekutif, Pemilihan Umum, Kekuasaan Kehakiman atau Kekuasaan Yudikatif mencakup keseluruhan peradilan yakni proses dan kelembagaan penegak hukum, Pengelolaan Keuangan Negara termasuk Untuk APBN dan APBD, Sistem Perekonomian Nasional dan Kesejahteraan Sosial, Sistem Perencanaan Nasional, Administrasi Pemerintahan dan Pelayanan Publik, Badan Hukum, Wilayah Negara, Kewarganegaraan, Hak Asasi Manusia, Sistem Pendidikan Nasional, Sistem Teknologi, Sistem Kesehatan Nasional, Lingkungan Hidup, Kebudayaan Nasional, Pertahanan Negara dan Keamanan Negara, Bendera, Bahasa dan Lambang Negara, serta Lagu Kebangsaan, Kebencanaan, Sistem Transportasi Nasional, Keagamaan, Organisasi Kemasyarakatan. 
Hasil identifikasi di atas ditemukan 2 (dua) perumpunan besar undang-undang di Indonesia yakni perumpunan bidang dan kelembagaan dalam UUD 1945. Pertama, perumpunan bidang berarti memuat proses, penyelenggaraan bidang-bidang kewenangan, hubungan antar pemerintahan dengan warga negara, hubungan antar warga negara. Kedua, perumpunan kelembagaan memuat kedudukan, struktur organisasi, jabatan-jabatan pemangku kewenangan, tugas pokok, fungsi, sistem rekrutmen. Kedua rumpun ini tidak dapat dipisahkan satu sama lain secara mutlak pada materi muatan setiap undang-undang. Setiap rumpun dan bagian dari rumpun (subrumpun) yang diatur dalam undang-undang akan terhubung satu sama lain. Misalnya, ketika mengatur tentang suatu bidang, di dalamnya akan terdapat struktur organisasi, kewenangan dan pelaksanaan kewenangan.

Kegunaan perumpunan ini, pertama, untuk memudahkan penataan dalam perencanaan, pelaksanaan dan penegakan melalui reformasi regulasi secara mendasar dan menyeluruh di Indonesia. Kedua, sinkronisasi (Nur, 2018) dan harmonisasi pengaturan (Syahlan, 2019), sehingga meminimalisir, bahkan menghilangkan terjadinya konflik kewenangan, konflik antar aturan; ketiga, meminimalkan kemungkinan terjadi penolakan berlakunya sebuah peraturan, karena relatif bisa diterima oleh masyarakat dengan syarat perencanaan melibatkan semua pihak berkepentingan, transparan. Keempat, memudahkan evaluasi peraturan perundang-undangan dalam rangka perubahan, pencabutan atau pembentukan yang baru sesuai dengan perkembangan kebutuhan hukum masyarakat (Aulia, 2020).

Sub-rumpun (lebih sempit) tidak dapat dibentuk menjadi UU tersendiri, apalagi sampai mengubah, menghapus, dan bahkan membentuk norma baru yang terpisah dari rumpun (lebih luas). Cara inilah yang seharusnya dilakukan mengawali penggunaan metode omnibus law dalam pembentukan perundang-undangan di Indonesia. Penggunaan metode ini, bagi
Indonesia merupakan keniscayaan untuk mewujudkan keadilan, kepastian, dan kemanfaatan hukum.

Sisi baik teknik ini, memungkinkan dibentuk satu UU terpadu (omnibus bill) yang berisi perubahan atau bahkan penggantian beberapa UU sekaligus diajukan ke parlemen untuk mendapatkan persetujuan dalam satu kesempatan pengambilan keputusan. Keuntungan teknik ini adalah pembentukan undang-undang berlangsung lebih cepat serta meniadakan tumpang-tindih, duplikasi, dan repetisi ketentuan yang biasa dialami saat teknik konvensional (non-omnibus bill) diterapkan (Thohari, 2019).

Penggunaan omnibus law sebagai metode dalam pembentukan peraturan bidang lingkungan hidup, akan membuat produk legislasi termasuk rumpun bidang akan menjadi lebih berkualitas. Namun demikian ini bukan merupakan "kereta cepat" pembentukan sebuah peraturan apalagi setingkat undang-undang. Seperti UU Cipta Kerja (UU-CK), dari sisi proses banyak dikeluhkan, karena tidak sepenuhnya memberi kesempatan para pihak terkait seperti buruh dalam hal ketenagakerjaan, para penggiat lingkungan, masyarakat adat, relatif tertutupnya akses informasi, bahkan naskah akademik dan draft RUU memunculkan "kesimpangsiuran" bagi kalangan akademisi.

Jadi, teknik ini juga memiliki kekurangan karena cakupan isu yang diatur sangat luas dan banyak, omnibus lawmaking technique ini seringkali membatasi peluang untuk diskusi, partisipasi, dan pengawasan publik demi mengejar kecepatan pengesahan RUU menjadi UU. Karena itu, banyak pihak menilai bahwa teknik ini kurang demokratis. Teknik ini lazim diterapkan di negara-negara dengan tradisi common law system semacam Amerika Serikat, Kanada, dan Australia, khususnya saat kegiatan ekonomi mencapai puncaknya (Thohari, 2019).

Terlepas dari kedua sisi penggunaan metode ini, "omnibus law-making technique ini sekadar teknik pembentukan undang- 
undang yang menyangkut pilihan metode belaka. Maka sebagai sebuah metode pembentukan peraturan, gagasan omnibus law oleh Presiden dapat diterapkan di Indonesia meskipun cenderung lebih dekat dengan tradisi civil law system"(Thohari, 2019).

Metode ini dalam pembentukan peraturan perundang-undangan di Indonesia sebenarnya pernah dilakukan, adapun beberapa contoh di antaranya: Ketetapan Majelis Permusyawaratan Rakyat Nomor I/MPR/2003 tentang Peninjauan terhadap materi dan Status Hukum Ketetapan Majelis Permusyawaratan Rakyat Sementara dan Ketetapan Majelis Permusyawaratan Rakyat Republik Indonesia Tahun 1960 sampai Tahun 2002, dimana Ketetapan Majelis Permusyawaratan Rakyat dimaksud meninjau materi dan status hukum 139 (seratus tiga puluh sembilan) Ketetapan Majelis Permusyawaratan Rakyat dan Ketetapan Majelis Permusyawaratan Rakyat Sementara sekaligus dengan 1 (satu) produk hukum berupa Ketetapan Majelis Permusyawaratan Rakyat Tahun 2003 tersebut" (Thohari, 2019); dibentuknya Undang-Undang Nomor 9 Tahun 2017 tentang Penetapan Peraturan Pemerintah Pengganti Undang-Undang Nomor 1 Tahun 2017 tentang Akses Informasi Keuangan untuk Kepentingan Perpajakan Menjadi Undang-Undang (Redi, Chandranegara, \& Dkk, 2020); dan Undang-Undang Nomor 23 Tahun 2014 tentang Pemerintahan Daerah.

Penggunaan omnibus law dengan perumpunan bidang dan kelembagaan dapat dilakukan terhadap reformasi regulasi lingkungan hidup sebagai rumpun bidang. Cakupannya meliputi bidang-bidang lingkungan hidup yang selama ini disebut dengan sektor sumber daya alam (subrumpun). Jangkauan subtansinya dibatasi pada sub-sub rumpun yang telah ditentukan sebelumnya. Sementara terhadap rumpun bidang yang secara tidak langsung terkait, cukup dimasukkan dalam 1 (satu) pasal tentang keterkaitan dalam hal tertentu, namun subtansinya tetap diatur peraturan yang terkait tidak langsung tersebut. Inilah yang disebut langkah awal menuju keterpaduan dalam perlindungan dan pengelolaan lingkungan hidup.

UU Lingkungan hidup sebagai rumpun bidang didasarkan pada beberapa pendapat para ahli hukum lingkungan. Menurut Daud Silalahi "Pertama, dasar bagi peraturan pelaksanaannya baik tingkat pusat maupun di daerah dari semua aspek lingkungan; kedua, landasan untuk menilai dan menyesuaikan semua peraturan perundangundangan yang memuat ketentuan tentang segi-segi lingkungan hidup yang kini telah berlaku seperti antara lain peraturan perundang-undangan di bidang pengairan, perkebunan dan energi, kehutanan, perlindungan dan pengawetan/pelestarian alam, industri, pemukiman, tata ruang dan tata guna tanah" (Silalahi, 2001). Jadi, UUPLH merupakan ketentuan "pokok" bagi sub rumpun lingkungan hidup. Konsekuensinya, semua peraturan perundang-undangan bidang lingkungan hidup harus tunduk dan tidak bertentangan dengan UUPLH.

Peraturan perundang-undangan lingkungan yang dipersiapkan penyusunannya guna menunjang UULHUUPLH sebagai wadah menuangkan kebijaksanaan lingkungan diharapkan merupakan salah satu jalan keluar bagi masalah lingkungan (Rangkuti, 2005). Menurut Mochtar Kusumaatmaja, untuk tujuan tersebut hukum sebagai sarana pembangunan dan rekayasa sosial dengan peranannya sebagai agent of change merupakan tumpuan harapan bagi terwujudnya pembangunan berkelanjutan (Rangkuti, 2005). Semua peraturan perundang-undangan tersebut di atas dapat terangkum dalam satu sistem hukum lingkungan Indonesia (Silalahi, 2001). Norma hukum yang terdapat UU-PPLH merupakan ketentuan pokok yang menghendaki keterpaduan hukum lingkungan hidup Indonesia (Helmi, 2012).

Secara konseptual ini terdapat pada Ketentuan Umum UU-PPLH Pasal 1 angka 1, "Lingkungan hidup adalah kesatuan ruang dengan semua benda, daya, keadaan, dan 
makhluk hidup, termasuk manusia dan perilakunya, yang mempengaruhi kelangsungan perikehidupan dan kesejahteraan manusia serta makhluk hidup lain". Kata kunci pada konsep lingkungan hidup adalah "ruang". Berdasarkan Pasal 1 angka 1 UU No. 26 Tahun 2007 tentang Penataan Ruang, "Ruang adalah wadah yang meliputi ruang darat, ruang laut, dan ruang udara, termasuk ruang di dalam bumi sebagai satu kesatuan wilayah, tempat manusia dan makhluk lain hidup, melakukan kegiatan, dan memelihara kelangsungan hidupnya".

Kemudian, yang dimaksud perlindungan dan pengelolaan lingkungan hidup dalam hal ini adalah upaya sistematis dan terpadu yang dilakukan untuk melestarikan fungsi lingkungan hidup dan mencegah terjadinya pencemaran dan/atau kerusakan lingkungan hidup yang meliputi perencanaan, pemanfaatan, pengendalian, pemeliharaan, pengawasan, dan penegakan hukum (Pasal 1 angka 2). Walaupun pengertian ini lebih mengarah pada upaya pengendalian, namun kata "sistematis dan terpadu" membuktikan, UU ini menghendaki adanya kesatuan sistem hukum dalam rangka pengendalian dan pengelolaan lingkungan hidup di Indonesia.

Ketentuan umum di atas, menunjukkan oleh UU-PPLH mencakup sub-sub rumpun seperti kehutanan, pertambangan, perkebunan, pengairan dan kelautan. Ruang lingkup perencanaan, pemanfaatan, pengendalian, pemeliharaan, pengawasan, dan penegakan hukum perlindungan dan pengelolaan lingkungan hidup mencakup bidang-bidang sektoral tersebut.

Mengenai keterpaduan dalam penjelasan umum UU ini mengandung dua makna hukum. "Pertama, UU-PPLH mencakup pengaturan seperti kehutanan, perkebunan, pertanahan, pertanian, pengairan (sungai), kelautan, pertambangan, ruang udara juga sebagai sub rumpun. Seluruh norma sub rumpun harus mengacu pada UU-PPLH. Kedua, "sistem yang terpadu", menegaskan kedudukan UU-PPLH merupakan "pondasi" bagi pembinaan hukum lingkungan melalui peraturan perundang-undangan lingkungan nasional (Helmi, 2012).

Jelas bahwa substansi UU-PPLH memuat norma yang mencakup seluruh sektor lingkungan hidup. Saat ini sektorsektor tersebut masing-masing diatur dengan UU tersendiri dan diselenggarakan oleh masing-masing lembaga mulai tingkat nasional (Kementerian) sampai daerah (Dinas). Inilah titik masuk penataan regulasi melalui omnibus law dengan menggunakan konsep lingkungan hidup sebagai payung terhadap bidang-bidang sektoral di Indonesia (Helmi, 2011).

\section{UU-PPLH sebagai Rumpun untuk Reformasi Regulasi terhadap Sektor Lingkungan Hidup di Indonesia}

Lingkungan hidup dalam UUD 1945 terdapat pada Pasal $28 \mathrm{H}$ ayat (1) yakni, "Setiap orang berhak hidup sejahtera lahir dan batin, bertempat tinggal, dan mendapatkan lingkungan hidup baik dan sehat serta berhak memperoleh pelayanan kesehatan". Pasal ini memberi pengakuan atau komitmen konstitusional terhadap lingkungan hidup yang memiliki hak (Jonaidi \& Wibisana, 2020). Berdasarkan landasan ini dan makna lingkungan hidup sebagaimana diuraikan pada sub-pertama, bahwa lingkungan hidup (UU-PPLH) merupakan rumpun bidang yang mencakup sub-sub rumpun bidang yang selama ini disebut dengan istilah sumber daya alam.

Dalam UU Cipta Kerja terdapat 25 (dua puluh lima, tidak termasuk UU-PPLH) undang-undang yang merupakan bagian rumpun bidang lingkungan hidup yang diubah, dihapus, dan/atau ditetapkan pengaturan baru, yakni: a) Undang-Undang Nomor 26 Tahun 2007 tentang Penataan Ruang; b) Undang-Undang Nomor 27 Tahun 2007 tentang Pengelolaan Wilayah Pesisir dan Pulau-Pulau Kecil, sebagaimana telah diubah dengan Undang-Undang Nomor 1 Tahun 2014 tentang Perubahan Atas Undang-Undang Nomor 27 Tahun 2007 tentang Pengelolaan Wilayah Pesisir dan Pulau-Pulau Kecil; c) Undang-Undang 
Nomor 32 Tahun 2014 tentang Kelautan; d) Undang-Undang Nomor 4 Tahun 2011 tentang Informasi Geospasial; e) UndangUndang Nomor 32 Tahun 2009 tentang Perlindungan dan Pengelolaan Lingkungan Hidup; f) Undang-Undang Nomor 31 Tahun 2004 tentang Perikanan, sebagaimana telah diubah dengan UndangUndang Nomor 45 Tahun 2009 tentang Perubahan Atas Undang-Undang Nomor 31 Tahun 2004 tentang Perikanan; g) UndangUndang Nomor 39 Tahun 2014 tentang Perkebunan; h) Undang-Undang Nomor 29 Tahun 2000 tentang Perlindungan Varietas Tanaman; i) Undang-Undang Nomor 22 Tahun 2019 tentang Sistem Budi Daya Pertanian Berkelanjutan; j) Undang-Undang Nomor 13 Tahun 2010 tentang Hortikultura; k) Undang-Undang Nomor 18 Tahun 2009 tentang Peternakan dan Kesehatan Hewan, sebagaimana telah diubah dengan UndangUndang Nomor 41 Tahun 2014; 1) UndangUndang Nomor 41 Tahun 1999 tentang Kehutanan, sebagaimana telah diubah dengan Undang-Undang Nomor 19 Tahun 2004 tentang Peraturan Pemerintah Pengganti Undang-Undang Nomor 1 Tahun 2004 tentang Perubahan Atas UndangUndang Nomor 41 Tahun 1999 tentang Kehutanan menjadi Undang-Undang; m) Undang-Undang Nomor 18 Tahun 2013 tentang Pencegahan dan Pemberantasan Perusakan Hutan; n) Undang-Undang Nomor 4 Tahun 2009 tentang Pertambangan Mineral dan Batubara, sebagaimana telah diubah dengan Undang-Undang Nomor 3 Tahun 2020 tentang Perubahan Atas Undang-Undang Nomor 4 Tahun 2009 tentang Pertambangan Mineral dan Batubara; o) Undang-Undang Nomor 22 Tahun 2001 tentang Minyak dan Gas Bumi; p) Undang-Undang Nomor 21 Tahun 2014 tentang Panas Bumi; q) Undang-Undang Nomor 30 Tahun 2009 tentang Ketenagalistrikan; r) Undang-Undang Nomor 10 Tahun 1997 tentang Ketenaganukliran; s) Undang-Undang 3 Tahun 2014 tentang Perindustrian; t) Undang-Undang Nomor 1 Tahun 2011 tentang Perumahan dan Kawasan
Permukiman; u) Undang-Undang Nomor 20 Tahun 2011 tentang Rumah Susun; v) Undang-Undang Nomor 2 Tahun 2017 tentang Jasa Konstruksi; w) Undang-Undang Nomor 17 Tahun 2019 tentang Sumber Daya Air; x) Undang-Undang Nomor 18 Tahun 2012 tentang Pangan; y) Beberapa ketentuan dalam Undang-Undang Nomor 2 Tahun 2012 tentang Pengadaan Tanah bagi Pembangunan untuk Kepentingan Umum; dan, z) Undang-Undang Nomor 41 Tahun 2009 tentang Perlindungan Lahan Pertanian Pangan Berkelanjutan.

UU Nomor 32 Tahun 2009 tentang Perlindungan dan Pengelolaan Lingkungan Hidup (UU-PPLH), walaupun masuk dalam daftar UU yang diubah, dihapus dan/atau ditetapkan ketentuan baru di dalamnya, namun untuk kajian ini UU-PPLH sebagai rumpun bidang yang seharusnya mengatur 25 (dua puluh lima) UU sub rumpun bidang lingkungan hidup di atas. Hal ini didasarkan pada konsep lingkungan hidup yang mencakup seluruh isi ruang.

Cipta kerja sebagai sub rumpun dari Sistem Perekonomian Nasional dan Kesejahteraan Sosial tidak boleh mengatur bahkan terkesan membawahi Lingkungan Hidup sebagai rumpun bidang, seperti terhadap terhadap UU-PPLH. Pasal 22 UU Cipta Kerja mengubah: Pertama, Pasal 1 angka 11 , angka 12 , angka 35 , angka 36 , angka 37, dan angka 38. Kedua, mengubah Pasal 20 tentang pencemaran dan baku mutu lingkungan hidup. Ketiga, mengubah Pasal 24 sampai Pasal 28 tentang AMDAL. Keempat, menghapus Pasal 29 sampai Pasal 31 tentang Komisi Penilai AMDAL. Kelima, mengubah Pasal 32 tentang penyusunan AMDAL. Keenam, mengubah Pasal 34, 35 tentang UKL-UPL. Ketujuh, mengubah izin lingkungan menjadi persetujuan lingkungan hidup, demikian seterusnya menghapus dan mengubah pasal-pasal tentang perizinan, sampai dengan Pasal 112.

Substansi UU-PPLH berpindah pada UU Cipta Kerja dengan 27 pasal diubah, 10 Pasal dihapus dan terdapat 4 pasal baru yang "disisipkan". Ditambah lagi UU Cipta memperlakukan sama terhadap sub-rumpun 
pada UU Sektoral yakni Penataan Ruang, Pertambangan, Perkebunan, Kehutanan, Pertanian, Sumberdaya Air, Perikanan. Alhasil, UU-PPLH sebagai rumpun yang seharusnya mengatur sub-sub rumpun bidang lingkungan hidup, justru kehilangan "mahkota" norma oleh UU Cipta Kerja.

Kembali pada hasil inventarisir di atas, untuk kepentingan reformasi regulasi, setelah ditentukan lingkungan hidup sebagai rumpun bidang yang mencakup 25 (dua puluh lima) sub rumpun, selanjutnya dilakukan penyusunan naskah akademik RUU Lingkungan Hidup (RUU-LH). RUU ini nantinya tidak sekedar melakukan kodifikasi, tapi juga sinkronisasi pengaturan rumpun lingkungan hidup di Indonesia. Diharapkan prinsip keterpaduan dalam pengelolaan lingkungan hidup yang selama ini menjadi cita-cita para tokoh lingkungan hidup dan hukum lingkungan di Indonesia dapat terwujud.

Pembaruan UU lingkungan hidup melalui metode omnibus law dirumuskan dengan keutamaan keseimbangan kepentingan ekonomi, sosial dan ekologi. Lingkungan hidup tidak semata dipandang sebagai faktor produksi untuk eksploitasi demi memenuhi target-target pendapatan negara melalui pajak, retribusi, dan pungutan bukan pajak lainnya. Namun lebih jauh lagi kepentingan pembangunan berkelanjutan yang mengutamakan untuk "mencapai keadilan dengan mendasarkan pada pertimbangan moral, maka dibutuhkan sebuah hukum sebagai fungsi pengintegrasi diantara berbagai kepentingan yang ada" (Nugroho, 2019).

Dalam pembangunan yang semata mengutamakan kepentingan ekonomi, Max Weber menyatakan, hukum sangat dipengaruhi oleh faktor ekonomi, maka bentuk-bentuk hukum akan berkembang pesat dengan perkembangan masyarakat yang bersangkutan. Misalnya dalam dinamika bentuk hukum yang formalrasional adalah sesuai dengan kepentingan kapital mendasarkan diri pada utilitarianism, memaksimalkan profit etik tanggung jawab individu, dapat diprediksi, serta secara efektif menjamin perencanaan (Redi et al., 2020).

Dalam proses pembangunan ekonomi, para kapitalis yang mendapatkan tempat, sementara masyarakat hukum adat berada dalam posisi yang tidak menguntungkan. Hukum yang memenuhi pada kepentingan kapitalis lebih dominan pada ketentuan hukum yang formal-rasional. Sehingga dalam proses pembangunan ekonomi, posisi masyarakat minoritas dan masyarakat tradisional di negara berkembang termasuk Indonesia menjadi terpinggirkan. Perebutan kepentingan antara kelompok minoritas dan masyarakat tradisional dengan kelompok kapitalis yang berkolaborasi dengan elemen negara (eksekutif dan yudikatif) atas kebijakan di sektor agraria dan lingkungan hidup dalam konteks pembentukan dan pelaksanaan hukumnya menunjukkan pembangunan ekonomi tidak menguntungkan bagi kelompok minoritas dan tradisional tersebut (Redi et al., 2020).

Kondisi di atas diharapkan bisa diminimalisir menuju keseimbangan kepentingan antara masyarakat, perusahaan, dan elemen pemerintahan melalui pembentukan peraturan perundangundangan menggunakan metode omnibus law. Seperti yang dikemukakan Jimly Asshiddiqie, "Omnibus Law merupakan pola penyusunan suatu norma peraturan perundang-undangan secara tertulis yang bersifat sistematis dan terpadu dengan mendasarkan pada prinsip-prinsip pembentukan peraturan perundangundangan" (Asshiddiqie, 2019).

Sub-sub rumpun bidang lingkungan hidup yang selama ini terpisah-pisah dalam berbagai undang-undang dibentuk menjadi satu undang-undang yakni undang-undang lingkungan hidup. UU ini nantinya menjadi pedoman dalam pengelolaan lingkungan hidup di Indonesia. Sehingga, pengaturan pengelolaan lingkungan hidup menjadi lebih sinkron dan harmonis, mudah dipahami dan dilaksanakan tanpa kuatir terjadi pertentangan norma, pertentangan kewenangan. 


\section{Simpulan dan Saran}

Simpulan dari penelitian ini adalah: pertama, UUD 1945 sebagai "pengikat simpul" setiap rumpun bidang dan kelembagaan dalam penyelenggaraan pemerintahan dan pembangunan di Indonesia. Perumpunan bidang dan kelembagaan dapat dijadikan sebagai dasar reformasi regulasi bidang lingkungan hidup menggunakan omnibus law. Perumpunan bidang dan kelembagaan inilah yang seharusnya ditemukan dan ditetapkan terlebih dahulu sebelum menyusun naskah akademik dan RUU. Kedua, lingkungan hidup merupakan rumpun bidang, maka omnibus law dapat dijadikan metode dalam pembentukan UU Lingkungan Hidup yang baru di Indonesia yang mencakup sektor lingkungan hidup sebagai sub-rumpun bidang diantaranya kehutanan, pertambangan, kelautan, perkebunan, sungai.

Berdasarkan simpulan, beberapa saran perlu diutarakan. Pertama, menindaklanjuti hasil penelitian, maka perlu dilakukan kajian untuk Naskah Akademik RUU dan RUU tentang Lingkungan Hidup menggunakan omnibus law. RUU ini nantinya sebagai pengganti UU-PPLH, hasilnya disampaikan kepada DPR atau Pemerintah. Kedua, materi muatan RUU Lingkungan Hidup ini terhubung dan menjadi rujukan norma teknis bidang lingkungan hidup yang telah diatur terlebih dahulu dalam UU Cipta Kerja.

\section{DAFTAR PUSTKA}

Anggono, B. D. (2014). Perkembangan Pembentukan Undang-Undang di Indonesia. (R. T. Budiarti, Ed.) (1st ed.). Konstitusi Press.

Asshiddiqie, J. (2005). Implikasi Perubahan UUD 1945 Terhadap Pembangunan Hukum Nasional. Jakarta.

Asshiddiqie, J. (2019). Kelebihan dan Kekurangan Sistem Kodifikasi dan Omnibus Law Serta Kombinasi Keduanya (FGD Pejabat Penentu Perancang Peraturan Perundang-
Undangan Antarkementerian di Badan Pembinaan Hukum Nasional (BPHN)). Jakarta.

Aulia, M. Z. (2020). Friedrich Carl von Savigny tentang Hukum: Hukum sebagai Manifestasi Jiwa Bangsa. Undang: Jurnal Hukum, 3(1), 221-226. http://doi.org/10.22437/ujh.3.1.201-236

Busroh, F. F. (2017). Konseptualisasi Omnibus Law Dalam Menyelesaikan Permasalahan Regulasi Pertanahan. Arena Hukum, 10(2), 227-250. http://doi.org/10.21776/ub.arenahukum. 2017.01002.4

Helmi, H. (2011). Membangun Sistem Perizinan Terpadu Bidang Lingkungan Hiduo di Indonesia. Jurnal Dinamika Hukum. http://doi.org/10.20884/1.jdh.2011.11.1. 86

Helmi, H. (2012). Hukum Perizinan Lingkungan Hidup. (Sinar grafika, Ed.) (ke-1). Jakarta: Sinar Grafika.

Helmi, H., Syam, F., Nopyandri, N., \& Putra, A. K. (2020). Evaluation of the Regulation Changes on Environment and Forestry in Indonesia. Hasanuddin Law Review, 6(1), 100-108. http://doi.org/10.20956/halrev.v6i1.229 0

Irwansyah. (2020). Refleksi Hukum Indonesia. (M. H. Ahsan Yunus, S.H., Ed.) (1, Juni 20 ed.). Yogyakarta: Mirra Buana Media.

Jonaidi, D. P., \& Wibisana, A. G. (2020). Landasan Doktriner Hak Gugat Pemerintah Terhadap Kerugian Lingkungan Hidup Di Indonesia. Jurnal Bina Mulia Hukum, 5(1), 156-175. http://doi.org/10.23920/jbmh.v5i1.9

Naskah Akademik RUU Cipta Lapangan Kerja. (2020), 1-9.

Nasution, B. J. (2008). Metode Penelitian Ilmu Hukum. Bandung: Mandar Maju. 
Nugroho, W. (2017). Rekonstruksi Teori Hukum Pembangunan Kedalam Pembentukan Perundang-Undangan Lingkungan Hidup. Jurnal Legislasi Indonesia, Vol. 14(4), 374.

Nugroho, W. (2019). Konsep Integrasi Kebijakan Pengelolaan Pertambangan Perspektif Pluralisme Hukum Di Indonesia. Masalah-Masalah Hukum, 48(4), 402. http://doi.org/10.14710/mmh.48.4.2019. 402-410

Nur, I. T. (2018). Memantapkan Landasan Hukum Formil Sebagai Alat Sinkronisasi Dan Harmonisasi Peraturan Perundang-Undangan. Yuriska: Jurnal Ilmu Hukum, 10(2), 266-287. http://doi.org/10.24903/yrs.v10i2.355

Puspitawati, D. (2020). Penerapan Konsep Omnibus Law Pada Pengaturan Kewenangan Penegakan Hukum Di Laut. Masalah-Masalah Hukum, 49(4), 393-408.

http://doi.org/10.14710/mmh.49.4.2020. 393-408

Rangkuti, S. S. (2005). Hukum Lingkungan dan Kebijaksanaan Lingkungan Nasional. Surabaya: Airlangga University Press.

Redi, A., Chandranegara, I. S., \& Dkk. (2020). Omnibus Law Diskursus
Pengadopsiannya Ke Dalam Sistem Perundang-Undangan Nasional. (Yayat Sri Hayati, Ed.) (1st ed.). Rajawali Pers.

RUU Omnibus Law Dinilai Tak Punya Pijakan Hukum. (n.d.).

Siaran Pers Telkom. (n.d.).

Silalahi, M. D. (2001). Hukum Lingkungan Dalam Sistem Penegakan Hukum Lingkungan Indonesia. Bandung: Alumni.

Sucahyo, N. (n.d.). Omnibus Law Jangan Berhenti di Soal Investasi.

Syahlan. (2019). Rekonstruksi Penataan Peraturan Perundang-Undangan Pasca Berlakunya Undang-Undang Nomor 12 Tahun 2011 tentang Pembentukan Peraturan Perundang-Undangan. Wacana Hukum: Jurnal Fakultas Hukum Universitas Slamet Riyadi, 25(1), 94-117.

Thohari, A. A. (2019). Menakar Omnibus Law. Koran Sindo, p. 3. Jakarta.

Widiati, E. P. (1945). Pendelegasian Pengaturan Oleh Undang-Undang Hukumnya, 141-156.

Wiratmadinata, W. (2018). Memahami Kembali Rumpun Ilmu Hukum Tata Negara. Jurnal Hukum Samudra Keadilan, 13(1), 44-66. http://doi.org/10.33059/jhsk.v13i1.731 